\title{
MONITORING GLACIER VARIATIONS IN THE SOUTHERN PATAGONIA ICEFIELD UTILIZING IMAGES LANDSAT 7 ETM+
}

\author{
Luís Felipe Ferreira de Mendonça ${ }^{\mathrm{a}}$ \\ ${ }^{1}$ CEPSRM, Universidade Federal do Rio Grande do Sul, Porto Alegre, Brazil. \\ lfelipem@msn.com
}

COMMISSION VIII, WG VIII/10 - Cryosphere

KEYWORDS: Cryosphere, Glaciology, Glacier Variation, Landsat 7, Database

\begin{abstract}
:
The monitoring of the variation in glacier areas is increasingly important with the apparent trend of global warming. One of the major ice sheets on the planet, the main glaciers of Southern Patagonia Icefield were mapped using a set of images obtained in 1973, 1976, 1979, 1986, 2005 and 2009 by the ETM + sensor onboard the Landsat 7 satellite. The images were calibrated to planetary radiance and reflectance, where the supervised classification of each image sought to obtain the physical limit of the snow with each glacier. Maps were generated with the terminal position of the glacier tongue for the dates analyzed. The results were compared with previous publications and showed peculiar behavior of each glacier, especially from the images of 1986, where there was a pattern of decrease in surface area of glaciers. And the temporal analysis will show the behavior of glaciers to the present day.
\end{abstract}

\section{INTRODUCTION}

The Patagonian Ice Field is the second largest glacier in the Southern Hemisphere. Located at the southern tip of South America, moves on the border between Argentine and Chilean territories. Composed of two large regions: the Northern Patagonia Icefield (NPI) and the Southern Patagonia Icefield (SPI), with areas of approximately $4.200 \mathrm{~km}^{2}$ and $13.000 \mathrm{~km}^{2}$ respectively. In the light of an apparent trend of global warming in recent years, it is important the monitoring of the variations of several glaciers on a global scale. With emphasis on temperate glaciers, which tend to respond to climate changes in a relatively short period of time.

With the passing of years the studies about global warming, and the behavior of glacier areas, have been intensified all over the world. With the Patagonian ice field wasn't no different and several authors have studied its glaciers since 1950 .

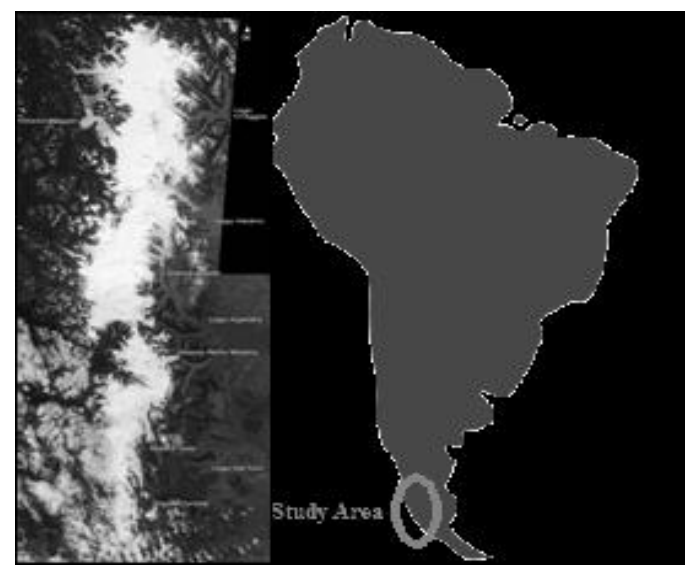

Figure 1. Study area - Mosaic of two digital photographs of Southern Patagonia Icefield.

Currently, most studies are conducted for specific glaciers, for example as the Moreno glacier (ANIYA, 1992(1); ROTT, 1998; STUEFER, 1999), Upsala (ANIYA, 1992 (1); SKVARCA, 1995), Bruggen (IWATA, 1983; 
RIVERA, 1999), Tyndall (CASASSA, 1992; RAYMOND, 2005) and O'higgins (KRIMMEL 1988).

Estimates indicate that Southern Patagonia Icefield will reduce of $38,7 \pm 4,4 \mathrm{~km}^{3} /$ year between the years 1975-2000, suggesting an acceleration rate of melting quite high. The Intergovernmental Panel on Climate Changes (2007) showed that the losses accumulated since 1960 in Patagonia are approximately 40m ice thickness, calculated over the glacier (LEMKE et al., 2007). This study aims to calculate the surface area of the main glaciers of Southern Patagonia Icefield through the digitalization of Landsat 7 ETM+ images obtained in the years 1973, 1976, 1979, 1986, 2005 and 2009.

\section{DATA AND METHODOLOGY}

The Southern Patagonia Icefield limited by coordinates to $74^{\circ} 10^{\prime}-73^{\circ} 30^{\prime} \mathrm{W}$ and $48^{\circ} 20^{\prime}-$ $51^{\circ} 30 \mathrm{~S}$ is approximately $60 \mathrm{~km}$ wide, $350 \mathrm{~km}$ in length and a total area of $13.000 \mathrm{~km}^{2}$. The glaciers studied were selected based on size, location and the existence of past studies to compare the results. The digitization and classification was done from a database of 24 images of the ETM + sensor aboard the Landsat 7 satellite, with a spatial resolution of $30 \mathrm{~m}$ and georeferenced in WGS84 datum obtained in the years 1973, 1976, 1986, 2005 and 2009. The images were acquired in the virtual portals of United States Geological Survey (USGS) and National Institute for Space Research (INPE).

The methodology was developed with help of software ENVI $4.5 \odot 2008$ and CartaLinx 1.2 () 1999 where Landsat images were calibrated to radiance and reflectance for a global standardization method. The calibration procedures employed in this study were used according to Chander and Markham (2003).

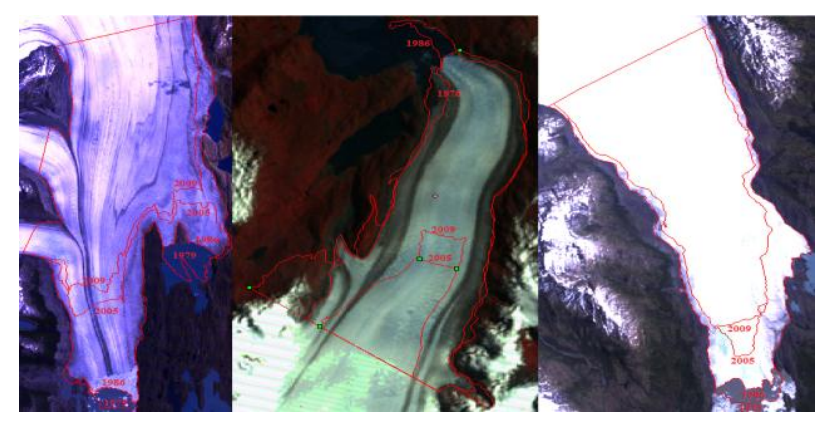

Figure 2. Linhas de variação na posição da língua das Geleiras Upsala, Jorge Montt e Tyndall. Geradas a partir de imagens Landsat 7 ETM+ para os de 1973-1976-19791986-2005-2009.

The digitization of each glacier was made in order to obtain the limiting position of the tongue (Figures 2 and 3), where each image was classified individually to avoid overlapping the range of pixels. Areas composed of multiple regions and pixel border between snow and sediment were excluded to avoid overlapping values and false classifications. Been generated lines of advance indicating the ceiling for each glacier for the period analyzed. Researchers such as Warren \& Sugden (1993) and Aniya et al. $(1992,1996)$ showed that the main glaciers of Southern Patagonia Icefield presented until the beginning of the decade 90 a general pattern of decline and reduced its volume, with exception of some glaciers showed a profile of frontal accretion and growth.

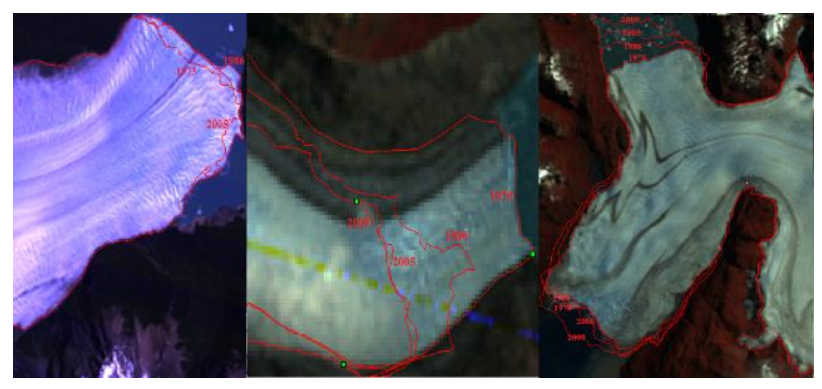

Figure 3. Linhas de variação na posição da língua das Geleiras Moreno, O'Higgins e Bruggen. Geradas a partir de imagens Landsat 7 ETM+ para os de 1976-1979-19862005-2009.

Jorge Montt Glacier: Located within a fjord on the northern edge of the Southern Patagonia Icefield has the drainage flow to the north 
ending northwest at coordinates $48^{\circ} 18^{\prime} \mathrm{S}$ and $73^{\circ} 27^{\prime} \mathrm{W}$. With an area of $602 \mathrm{~km}^{2}$ in 1976 lost $63 \mathrm{~km}^{2}$ of total ice surface in the period 1976 1986 reaching $555 \mathrm{~km}^{2}$. The data obtained from the Landsat image of 2005 show a dramatic reduction in the volume of the glacier after a decrease of $10.060 \mathrm{~m}$ reached a surface area of $198 \mathrm{~km}^{2}$. Image data from 2009 show that an increase of $8 \mathrm{~km}^{2}$ ice surface area increased the total area of the glacier to $206 \mathrm{~km}^{2}$, due primarily to an advance of the tongue of $1,3 \mathrm{~km}$.

Bröggen Glacier: It is the only studied glacier on the west side of the Southern Patagonia Icefield and is among the highest volume glaciers. Located at $49^{\circ} 10^{\prime} \mathrm{S}-75^{\circ} 53^{\prime} \mathrm{W}$ has its terminal part forked north toward the lake Greve and south to the Eyre fjord. In recent decades, it has shown a very unusual behavior compared to other glaciers in the Southern Patagonia Icefield, opposed the others it has increased its area with a steady growth of the tongue through the years. With an area of approximately $1.604 \mathrm{~km}^{2}$ in 1976 was increased its total area to $1.653 \mathrm{~km}^{2}$ after a breakthrough of $800 \mathrm{~m}$ in image 1986 . The data show that the tongue North increased $21 \mathrm{~km}^{2}$ in the period 1976-1986 while the tougue area south maintained your area stable. The image of 2005 shows a decrease in the glacier total area of $148 \mathrm{~km}^{2}$, but the tongue north continued to grow about $550 \mathrm{~m}$. The pattern of growth recorded by other authors in the images obtained in 2009 the glacier increased its $130 \mathrm{~km}^{2}$ in total area compared to 2005. Adding in the period 1986-2009 a total advance of approximately $18 \mathrm{~km}^{2}$.

O'Higgins Glacier: Located in upper side of the ice field at coordinates $48^{\circ} 54^{\prime} \mathrm{S}$ and $73^{\circ} 12^{\prime} \mathrm{W}$, ends in an arm of Lake O'Higgins, who on the Argentine side is known as Lake St. Martin. This glacier has shown a very large number of recessions between 1945 and 1986, with a total of $13,4 \mathrm{~km}(327 \mathrm{~m} /$ year $)$ this value was considered exceptionally large in Patagonia, including the glaciers of the Northern Patagonia Icefield (ANIYA, 1988). With a total area of $440 \mathrm{~km}^{2}$ in 1976 it had its area decreased to $376,9 \mathrm{~km}^{2}$ after a decline to $1.460 \mathrm{~m}$ and a loss of $63,1 \mathrm{~km}^{2}$ in 1986. With lower indices of decline since the decade of 90 the glacier has reduced its total area to $347 \mathrm{~km}^{2}$ in 2005 , reaching $329,2 \mathrm{~km}^{2}$ in 2009 .

Upsala Glacier: Considered one of the largest glaciers in South America, Upsala is located on the east side of the ice field in the coordinates $49^{\circ} 51^{\prime} \mathrm{S}$ and $73^{\circ} 16^{\prime} \mathrm{W}$.It had retreated constantly until the decade of 60 (ANIYA, 1992), passing at a decline rate of decline of $2.300 \mathrm{~m}$ (135m/year) during the period from 1969 to 1986, measured near the center of the glacier. Values obtained for the glacier in this study showed a surface area for the year 1979 of $1.596 \mathrm{~km}^{2}$ and $1.447,4 \mathrm{~km}^{2}$ in 1986 , declining approximately $2.100 \mathrm{~m}$ and a lost area of $148,6 \mathrm{~km}^{2}$ area in the period $1979-1986$. Between the years 1986 and 2005 the loss was $377 \mathrm{~km}^{2}$ on the surface, to come in 2009 with a total area of $917,4 \mathrm{~km}^{2}$, reducing approximately $530 \mathrm{~km}^{2}$ in the period $1986-2009$.

Moreno Glacier: Moreno is located in the lower east side of the Southern Patagonia Icefield in $50^{\circ} 29^{\prime} \mathrm{S}$ and $73^{\circ} 06^{\prime} \mathrm{W}$, has its forked tongue to the north and east flowing toward an arm of Lake Argentino. Among the studied glaciers Moreno was the one with the lowest levels of area variation and tongue movement. Data obtained from Landsat image shows that to the glacier were about $538 \mathrm{~km}^{2}$ area in 1979, with an increase of approximately $480 \mathrm{~m}$ of the glacier tongue the total area was increased to $557 \mathrm{~km}^{2}$ in 1986 . Since the decade of 90 to the glacier began to show a retraction process very expressive, with practically stable behavior in 20 years. The values obtained 
for the total area of glacier were $513 \mathrm{~km}^{2}$ in 2005 and $507 \mathrm{~km}^{2}$ in 2009. This type of behavior less intense shows that for understanding the

dynamics of the glacier we need annual data and field studies, in order to know the real evolution of the glacier along time.

Tyndall Glacier: Is the glacier studied more to the south of the Southern Patagonia Icefield with approximately $40 \mathrm{~km}$ in length, flows into the lake pro-glacial Geikie originated from it. Located in the coordinates $51^{\circ} 12^{\prime} \mathrm{S}-73^{\circ} 18^{\prime} \mathrm{W}$ and is adjacent to the famous mountain of Paine. In 1973 the glacier had a total surface area of $507 \mathrm{~km}^{2}$ that after a decline of approximately $750 \mathrm{~m}$ had its area reduced to $449 \mathrm{~km}^{2}$ in 1986 and since then has suffered intense retreats of the tongue and reduction of the glacier total volume. Data from 2005 show a surface area of $380 \mathrm{~km}^{2}$ in a decrease of approximately approximately $1.300 \mathrm{~m}$ of tongue in relation to 1986. For the year 2009 images showed a further retraction to $2.650 \mathrm{~m}$ in relation to 1986 and a nice-covered area of $363 \mathrm{~km}^{2}$.

\section{RESULTS AND CONCLUSIONS}

Variations in the front area of the glaciers are important not only for the calculation of area, flow and speed, but in order to gain knowledge about the behavior of ice masses. The data in Table 1 show a evident tendency of retreated the glaciers from the first images. The exception Bruggen glacier that during the study period showed a growth profile in the region of discharge and body of the glacier. Upsala and Jorge Montt glaciers obtained the greatest loss of mass, with very accelerated process of retraction from the 90's. Jorge Montt is glacier studied with more troubling levels of retraction and volume loss, reaching approximately $50 \mathrm{~km}^{2} /$ year of ice area lost. The Moreno glacier showed during the century alternations of frenquent advances and retreats, with a behavior considered stable in your area during the years analyzed.

\begin{tabular}{|c|c|c|c|c|c|}
\hline \multicolumn{6}{|c|}{ Area lost $\left(\mathrm{km}^{2}\right)$} \\
\hline Glacier & $\begin{array}{c}1973- \\
1986 \\
\end{array}$ & $\begin{array}{c}1976- \\
1986 \\
\end{array}$ & $\begin{array}{c}1979- \\
1986 \\
\end{array}$ & $\begin{array}{c}1986- \\
2005 \\
\end{array}$ & $\begin{array}{c}2005- \\
2009 \\
\end{array}$ \\
\hline Jorge & & & & $357 \mathrm{~km}$ & (- \\
\hline Montt & $\mathrm{X}$ & $63 \mathrm{~km}^{2}$ & $x$ & 2 & $\begin{array}{c}18 \mathrm{~km}^{2} \\
(-\end{array}$ \\
\hline $\begin{array}{l}\text { Brugge } \\
n\end{array}$ & $X$ & $\stackrel{(-}{(-})$ & $x$ & $\begin{array}{c}148 \mathrm{~km} \\
2\end{array}$ & $\begin{array}{c}130 \mathrm{k} \\
\mathrm{m}^{2}\end{array}$ \\
\hline O'Higgi & & $63,1 \mathrm{k}$ & & $29,9 k$ & $47,7 \mathrm{k}$ \\
\hline ns & $X$ & $\mathrm{~m}^{2}$ & $\begin{array}{c}X \\
(-)\end{array}$ & $\mathrm{m}^{2}$ & $\mathrm{~m}^{2}$ \\
\hline Moreno & $X$ & $x$ & $\begin{array}{l}19 \mathrm{~km}^{2} \\
148,6 \mathrm{k}\end{array}$ & $\begin{array}{l}44 \mathrm{~km}^{2} \\
377 \mathrm{~km}\end{array}$ & $\begin{array}{c}6 \mathrm{~km}^{2} \\
153 \mathrm{~km}\end{array}$ \\
\hline Upsala & X & $x$ & $\mathrm{~m}^{2}$ & 2 & 2 \\
\hline Tyndall & $58 \mathrm{~km}^{2}$ & $x$ & $x$ & $69 \mathrm{~km}^{2}$ & $17 \mathrm{~km}^{2}$ \\
\hline
\end{tabular}

Table 1. Loss of frontal area of the glaciers due to retreat - 1973-2009.

Studying the conduct of Patagonian ice masses we must consider that obtaining field data and climatology in this region are very difficult, especially because it is a sparsely populated region with a limited number of meteorological stations and terrain complex. The values of retraction of glaciers indicate that the Southern Patagonia Icefield can be responding to climate change so quickly and intensely. Data of the Chilean Meteorological Office show that there was a significant increase in temperature in the region throughout the year, from 1986 until today. According Aniya (1992) the Patagonian glaciers are supposed to respond quickly to climatic changes, because they are characterized by a large mass balance, that is, large amounts of accumulation and ablation, and since the change in air temperature affects the snout area more quickly, it seems that these climatic trends would explain some glaciers' behaviors; however, naturally, not all of them. This work was elaborate from the analysis of surface area of glaciers, so we need more 
detailed studies in order to we be able to conclude that these variations in the body of the glaciers are really caused by global warming. However, it appears that the recent rapid recession is a response to the recent world-wide warming trend.

\section{ACKNOWLEDGEMENTS}

The authors are grateful to United States Geological Survey (USGS) and National Institute for Space Research (INPE) by images.

\section{REFERENCES}

ANIYA, M., 1988. Glacier inventory for the Northern Patagonia Icefield, Chile, and variations 1944/45 to 1985/86. Arctic and Alpine Research, 20: 179-187.

ANIYA (1), M., and SKVARCA, P., 1992. Characteristics and variations of Upsala and Moreno glaciers, southern Patagonia, Bulletin of Glacier Research, 10:39-53.

ANIYA (2), M., NARUSE, R., SHIZUKUISHI, M., SKVARCA, P. and CASASSA, G., 1992. Monitoring recent glacier variations in the Southern Patagonia Icefield, utilizing remote sensing data, International Archives of Photogrammetry and Remote Sensing, 29(B7):8794.

ANIYA, M., SATO, H., NARUSE, R., SKVARCA, P. and CASASSA, G., 1996. The use of satellite and airbone imagery to inventory outlet glaciers of the Southern Patagonia Icefield, South America. Photogrammetric Engineering and Remote Sensing, 62, pag. 1361-1369.

CASASSA, G., 1992. Radio-echo sounding of Tyndall Glacier, southern Patagonia. Bulletin of Glacier Research, 10: 69-74.

CHANDER, G., MARKHAM, B., 2003. Revised Landsat-5 TM Radiometric Calibration Procedures and Post calibration Dynamic Ranges, IEEE Transactions on Geoscience and Remote Sensing, Vol. 41, N ${ }^{\circ} 11$.
IWATA, S., 1983. Further advance of Pio XI Glacier. In Glaciological and Meteorological Studies in Patagonia, Chile, by Japanese Research Expeditions in 1967-1982 (Data Center for Glacier Researches, Japanese Society of Snow and Ice), 14- 17.

KRIMMEL, R. M., 1988. Terminus of Glacier O'Higgins, southern Chile. Journal of Glaciology, 34 (116): 142.

LEMKE, P., et al. 2007., Observations: Changes in snow, ice and frozen ground, in Climate Change 2007: The Physical Science Basis. Contribution of Working Group I to the Fourth Assessment Report of the Intergovernmental Panel on Climate Change, edited by S. Solomon et al., pp. 337- 383, Cambridge Univ. Press, New York.

RAYMOND, C., NEUMANN, I., RIGNOT, E., ECHELMEYER, K., RIVERA A. and CASASSA G., 2005. Retreat of Tyndall glacier, Patagonia, over the last half century. Journal of Glaciology.

ROOT, H., STUEFER M., SIEGEL A., SKVARCA P. and ECKSTALLER A, 1998. Mass fluxes and dynamics of Moreno Glacier, Southern Patagonia Icefield. Geophysical Research Letters, 25 (9), 1407-1410.

RIVERA, A. and Casassa G., 1999. Volume changes of Pío XI glacier: 1975-1995. Global and Planetary Change, 22(1-4), 233.

SKVARCA, P., SATOW, K., NARUSE, R. and LEIVA, J., 1995. Recent thinning, retreat and flow of Upsala Glacier, Patagonia, Bulletin of Glacier Research, 13:11-20.

STUEFER, M., 1999.. Investigations on mass balance and dynamics of Moreno Glacier based on field measurements and satellite Imagery. $\mathrm{PhD}$ dissertation, Leopold-Franzens-Univesitat, Innsbruck, p. 173.

WARREN, C.R. and SUGDEN, D.E., 1993. The Patagonian Icefields: A glaciological review, Arctic and Alpine Research, 25(4]:316-331. 